\title{
Kualitas Mikrobiologi Dendeng Sapi yang di Curring dengan Ekstrak Rosella (Hibiscus sabdariffa. L)
}

\section{Maria I. Nesi ${ }^{\mathrm{a}}$, Stefanus $\mathrm{Sio}^{\mathrm{b}}$ dan Kristoforus W. Kia ${ }^{\mathrm{c}}$.}

${ }^{a}$ Fakultas Pertanian, Universitas Timor, Kefamenanu, TTU - NTT, 85613, Indonesia,email: biimanesi097@ gmail.com

${ }^{b}$ Fakultas Pertanian, Universitas Timor, Kefamenanu, TTU - NTT, 85613, Indonesia,email: stefsio67@ gmail.com

cFakultas Pertanian, Universitas Timor, Kefamenanu, TTU - NTT, 85613, Indonesia,email: willykia71@ yahoo.co.id

\section{Article Info}

\section{Article history:}

Received 11 Juni 2019

Received in revised form 25 Juni 2019

Accepted 23 Juli 2019

DOI

https://doi.org/10.32938/ja.v4i3.724

\section{Keywords:}

Ekstrak rosella

Antibakteri

Zona hambat

S. aureus

Dendeng

\begin{abstract}
Abstrak
Tujuan dari penelitian ini adalah untuk mengetahui aktivitas antibakteri dari ekstrak rosella (Hibiscus sabdariffa L.) terhadap pertumbuhan bakteri Staphylococcus aureus dan kualitas mikrobiologi dari dendeng sapi yang di curing basah dengan ekstrak rosella. Metode uji yang digunakan yaitu metode difusi sumuran dan uji TPC menggunakan metode tuang (pour plate). Rancangan percobaan yang digunakan adalah rancangan acak lengkap yang terdiri dari: R0= Pembuatan dendeng + bumbu-bumbu (kontrol negatif); R1= Pembuatan dendeng + bumbu-bumbu + nitrat $200 \mathrm{ppm}(0,2 \mathrm{~g}) ; \mathrm{R} 2=$ Pembuatan dendeng + bumbu-bumbu + ekstrak rosella 40\%; R3= Pembuatan dendeng + bumbu-bumbu + ekstrak rosella $60 \%$. Hasil penelitian menunjukkan bahwa pada konsentrasi ekstrak rosella $40 \%$ dan 60\% memiliki kemampuan dalam menghambat pertumbuhan bakteri S.aureus dengan rerata yang diperoleh yaitu 3,41 mm dan 4,03 $\mathrm{mm}$. Sedangkan pada kontrol positif dan negatif tidak memiliki kemampuan dalam menghambat pertumbuhan bakteri. Hasil dari uj kualitas mikrobiologi dendeng sapi menunjukkan bahwa ekstrak rosella memiliki kemampuan bakteriostatik dengan nilai rerata yang diperoleh 28,33 dan 8,67 dan terbentuknya zona hambat (zona bening) pada konsentrasi $40 \%$ dan 60\%. Disimpulkan bahwa ekstrak rosella memiliki kemampuan sebagai antibakteri terhadap bakteri S.aureus dengan terbentuknya zona hambat (zona bening) pada konsentrasi $40 \%$ dan $60 \%$. Ekstrak rosella memiliki kemampuan dalam menghambat pertumbuhan koloni bakteri pada produk dendeng Pengawet sintetik (nitrat) tidak memiliki kemampuan dalam menghambat ataupun membunuh bakteri.
\end{abstract}

\section{Pendahuluan}

Daging sapi merupakan salah satu bahan pangan yang bernilai gizi tinggi dan sangat digemari oleh masyarakat. Kandungan nutrisi dari daging berupa air protein, lemak, mineral dan sedikit karbohidrat. Kandungan-kandungan yang tersedia ini menjadi medium yang baik untuk pertumbuhan bakteri dan menjadi daging mudah mengalami kerusakan (Nurwantoro et al., 2012). Sehingga diperlukan metode pengolahan yang tepat. Pengolahan daging sapi adalah salah satu metode alternatif yang sering digunakan untuk mengurangi resiko kerusakan daging sehingga dapat diperoleh nilai tambah dari produk yang dihasilkan. Produk daging sapi yang digemari oleh masyarakat Indonesia karena bersifat praktis dan merupakan panganan yang umur simpan relatif lama yaitu dendeng.

Dendeng merupakan salah satu produk olahan daging kering secara tradisional dan konvensional yang merupakan hasil suatu proses kombinas curing dan pengeringan, dengan memotong dalam bentuk lembaran tipis, kemudian ditambahkan garam sendawa, gula dan garam dapur $(\mathrm{NaCl})$ serta bumbu berupa rempah-rempah misalnya ketumbar, bawang putih, bawang merah, laos dan jahe (Bintoro, 2008).

Dalam industri pengolahan pangan sering digunakan pengawet sintetik untuk memperpanjang umur simpan suatu bahan pangan. Nitrat merupakan bahan tambahan pangan yang umumnya digunakan. Namun, penggunaan yang berlebihan dapat memberikan efek negatif bagi kesehatan konsumen. Menuru JECFA (2002), batas Acceptable Daily Intake (ADI) natrium nitrat untuk asupan harian yang dapat diterima oleh tubuh adalah $0-0,07 \mathrm{mg} / \mathrm{kg}^{-1}$ bobo badan hari ${ }^{-1}$. Adanya dampak yang buruk bagi kesehatan konsumen, maka perlu diganti dengan bahan pengawet alami. Hapsari (2010), menyatakan bahwa bahan-bahan alami memiliki aktivitas menghambat mikroba yang disebabkan oleh komponen tertentu yang ada didalamnya. Salah satu bahan alami yang berpotensi menggantikan peran nitrat sebagai bahan pengawet dan antimikroba alami yaitu rosella (Hibiscus sabdariffa L.).

Rosella termasuk family Malvaceae yang merupakan tanaman tropis yang banyak tumbuh di Indonesia. Kelopak bunganya biasa digunakan dalam pengobatan tradisional, seperti pengobatan penyakit batuk, gangguan pencernaan, menurunkan tekanan darah, merangsang gerak peristaltik usus serta berpengaruh terhadap diuretik (Suzery et al., 2010). Selain itu senyawa aktif dalam rosella yaitu alkaloid, polifenol, tannin, flavonoid, steroid dan saponin yang bekerja sebagai antibakteri (Komala et al., 2013). Sehingga cocok untuk diaplikasikan dalam produk pangan.Tujuan dari penelitian ini adalah untuk mengetahui aktivitas antibakteri dari ekstrak rosella (Hibiscus sabdariffa L.) terhadap pertumbuhan bakteri Staphylococcus aureus dan kualitas mikrobiologi dari dendeng sapi yang di curing basah dengan ekstrak rosella.

\section{Metode}

\subsection{Waktu dan Lokasi Penelitian}

Penelitian ini dilaksanakan di Laboratorium Mikrobiologi Universitas Widya Mandira Kupang, sejak tanggal 20 Februari 2019 sampai tanggal 30 Maret 2019

\subsection{Alat dan Bahan}

Alat-alat yang digunakan dalam penelitian ini adalah labu erlenmeyer, batang pengaduk, shacker, rotary evaporator, sendok, piring, gunting, pipe ukur, cawan petri, tabung reaksi, mikropipet, jarum ose, pembakar bunsen, vortex mixer, incubator (Firlabo), spatula, timbangan digital, magnetik stirrer, gelas kimia, gelas ukur, pipet tetes, pisau, jangka sorong, food processor, slicer oven, hot plate, colonu counter, kamera digital. Bahan-bahan yang digunakan terdiri dari daging sapi segar, gula merah, garam, ketumbar, lada, bawang putih, serbuk rosella, etanol 95\%, media Nutrient Agar (NA), biakan bakter
Staphylococcus sureus, kertas saring, kertas label, kapas, tissue, aluminium foil, kain ferban, aquades.

\subsection{Rancangan Penelitian}

Penelitian ini menggunakan Rancangan Acak Lengkap (RAL), terdiri dari

$\mathrm{R} 0=$ Pembuatan dendeng + bumbu-bumbu (kontrol negatif)

$\mathrm{R} 1=$ Pembuatan dendeng + bumbu-bumbu + nitrat $200 \mathrm{ppm}(0.2 \mathrm{~g})$

$\mathrm{R} 2=$ Pembuatan dendeng + bumbu-bumbu + ekstrak rosella $40 \%$

$\mathrm{R} 3=$ Pembuatan dendeng + bumbu-bumbu + ekstrak rosella $60 \%$

\subsection{Persiapan Bahan}

Persiapan bahan meliputi persiapan bumbu dan daging. Bumbubumbu rempah dan rosella dibersihkan kemudian dihaluskan menggunakan food processor. Daging yang digunakan adalah daging sapi bagian paha belakang kemudian daging diiris tipis $(5 \mathrm{~mm})$ menggunakan slicer.

\subsection{Ekstraksi Rosella}

Tahap ekstraksi rosella pada penelitian ini menggunakan metode maserasi yaitu proses perendaman sampel dengan etanol 95\%. Tahapan ekstraksi rosella sebagai berikut:

1. Serbuk rosella ditimbang sebanyak $600 \mathrm{~g}$ untuk setiap labu erlenmeyer dengan etanol 1 liter $(95 \%)$

2. Setelah dicampur lalu diaduk menggunakan batang pengaduk selama 30 menit dan dilanjutkan dengan proses shaker selama 15 menit

3. Setelah itu didiamkan di suhu ruang selama 24 jam

4. Selanjutnya dilakukan penyaringan untuk mendapatkan filtratnya menggunakan kertas saring

5. Setelah disaring dilanjutkan dengan rotav.

Ekstraksi rosella bertujuan mendapatkan senyawa antosianin dan fenolik dari rosella melalui metode ekstraksi secara maserasi. Ekstraksi rosella dilakukan dengan menggunakan metode maserasi yang dimodifikasi dari metode Cisse et al. (2009)

\subsection{Pembuatan Dendeng}

Tahap pembuatan dendeng sebagai berikut:

1. Daging dipotong dengan ketebalan 2,5- $5 \mathrm{~mm}$.

2. Daging dimasukan dalam wadah dan diberi bahan curing (bumbu, jus kelopak rosella merah dan nitrat sesuai perlakuan) sambil dilakukan peremasan.

3. Daging yang telah diiris tipis direndam dalam larutan nitrat dan ekstrak rosella selama 24 jam dalam suhu ruang.

4. Selanjutnya daging dikeringkan menggunakan oven pada suhu $60^{\circ} \mathrm{C}$ selama 3 jam, daging dibalik kemudian dilanjutkan pengeringan dengan suhu $70^{\circ} \mathrm{C}$ selama 5 jam.

5. Daging didinginkan lalu dikemas dengan plastik potietilen sesuai perlakuan

6. Selanjutnya sampel dibawah ke laboratorium dan dilakukan analisis

\subsection{Pengambilan Data}

Pengambilan data diambil setelah dendeng diberi perlakuan dan dilakukan pengujian terhadap antioksidan, pengukuran kadar air, pengukuran nilai $\mathrm{pH}$ dan total fenolik dendeng sapi.

\subsection{Analisis Data}

Analisis data dilakukan menggunakan analisis sidik ragam ANOVA dengan Rancangan Acak Lengkap (RAL) tunggal. Dilanjutkan dengan Duncan 
Multiple Range Test (DMRT) dengan tingkat signifikan 0,05\%. Analisis data penelitian menggunakan Software SAS 9.1.

\section{Hasil dan Pembahasan}

\subsection{Hasil uji antagonistik ekstrak rosella terhadap S.aureus}

S.aureus merupakan bakteri yang beradar dimana-mana seperti udara, debu, air, susu, makanan, peralatan makanan, lingkungan dan tubuh manusia atau hewan yang terdapat pada kulit, rambut/bulu dan saluran pernafasan. Manusia dan hewan merupakan sumber utama infeksi (Chotiah, 2009). Menurut Rahmi et al. (2015), bahwa bakteri S.aureus dapat menyebabkan terjadinya berbagai jenis infeksi ringan pada kulit, keracunan makanan sampai dengan infeksi sistematik. Bahan antibakteri diartikan sebagai bahan yang megganggu pertumbuhan dan metabolisme bakteri yang bersifat menghambat atau membunuh bakteri yang diketahui dari pengujian antibakteri. Salah satu metode yang pengujian daya antibakteri adalah difusi sumur. Metode ini dipilih karena lebih cocok dan praktis untuk uji herbal atau obat yang berasal dari tanaman. Metode pengukuran dan pengamatan diameter zona bening yang terbentuk disekitar sumur pada media nutrient agar (NA) setelah diinkubasi selama 18-24 jam dan diukur menggunakan jangka sorong.

Hasil pada Tabel 1 menunjukkan bahwa konsentrasi ekstrak rosella 40\% dan $60 \%$ pada media NA setelah ditumbuhi bakteri S. aureus yang telah diinkubasi selama 24 jam dengan suhu $37^{\circ} \mathrm{C}$ memiliki kemampuan dalam menghambat pertumbuhan bakteri $S$. aureus dengan ditunjukkan oleh adanya zona bening (diameter penghambat). Diamater penghambat yang terbentuk dipengaruhi oleh konsentrasi ekstrak, tingkat kelarutan ekstrak dan kemampuan ekstrak berdifusi dalam agar (Prescott et al., 2005). Selain itu, kemampuan dalam menghambat bakteri $S$. aureus didukung oleh hasil penelitian Rostinawati (2009) bahwa ekstrak rosella dapat menghambat pertumbuhan bakteri $S$. aureus dan bakteri $E$. coli pada media agar.

BerdasarkanTabel 1, nilai diamater penghambat tertinggi dihasilkan oleh konsentrasi ekstrak rosella $60 \%$ dengan rata-rata zona hambat yang terbentuk sebesar 4,03 mm. Nilai diameter penghambat pada konsentrasi lebih rendah yaitu $40 \%$ menghasilkan zona hambat $3,41 \mathrm{~mm}$. Diamater zona hambat ekstrak rosella mengalami penurunan sesuai dengan diturunkannya konsentrasi ekstrak yang diuji. Perbedaan nilai diamater hambat ekstrak rosella diduga dari aktivitas antibakteri senyawa aktif dari rosella lebih tinggi pada konsentrasi $60 \%$. Selain itu, hal ini diduga karena metode ekstraksi dan jenis pelarut yang digunakan dalam mengekstrak rosella untuk menghasilkan ekstrak polar tepat sehingga senyawa polar yang aktif terekstrak bersama pelarut. Menurut Khasanah (2014) bahwa semakin tinggi konsentrasi suatu ekstrak maka semakin tinggi komponen zat aktif yang terkandung didalamnya. Pada hasil pengamatan, efek antimikroba ekstrak rosella semakin meningkat pada konsentrasi $60 \%$. Adanya kinerja antibakteri yang stabil pada konsentrasi tinggi kemungkinan disebabkan karena senyawa-senyawa metabolik sekunder memberi peningkatan respon yang signifikan. Hal lain juga berkaitan dengan pelarut etanol $95 \%$ yang digunakan dalam ekstrak.

Ketentuan kekuatan daya antibakteri sebagai berikut : daerah hambatan $\geq$ $20 \mathrm{~mm}$ termasuk sangat kuat, daerah hambatan 10-20 mm kategori kuat, daerah hambatan 5-10 mm atau kurang termasuk kategori lemah (Mpila et al., 2012). Lemahnya kemampuan hambat ekstrak rosella dalam menghambat pertumbuhan $S$. aureus yang dibuktikan dengan hasil diamater hambatan $<5$ $\mathrm{mm}$ diduga akibat ekstrak rosella. Banyak senyawa yang terkandung dalam ekstrak kasar ini mengakibatkan adanya sifat saling meniadakan (antagonis) antar senyawa dalam ekstrak sehingga mengurangi aktivitas antibakteri ekstrak (Kapitan et al., 2017).

Hasil pengukuran pada bakteri uji $S$. aureus (Tabel 1) dapat diperlihatkan bahwa R0 tidak memiliki kemampuan dalam menghambat pertumbuhan bakteri sebagai kontrol negatif dengan tidak ditemukan zona bening pada daerah cawan. Hasil ini sama dengan penambahan nitrat yang tidak terdapat zona bening pada media NA. Hal ini membuktikan bahwa kandungan ekstrak rosella dapat menghambat pertumbuhan $S$. aureus.

$\underline{\text { Tabel 1. Hasil Uji Antagonistik ekstrak rosella terhadap S.aureus }}$

\begin{tabular}{ccccc}
\hline \multirow{2}{*}{ Perlakuan } & \multicolumn{3}{c}{ Ulangan } & \multirow{2}{*}{ Rata-rata } \\
\cline { 2 - 3 } & I $(\mathrm{mm})$ & II $(\mathrm{mm})$ & III $(\mathrm{mm})$ & \\
\hline R0 & 0,00 & 0,00 & 0,00 & $0,00^{\mathrm{c}}$ \\
R1 & 0,00 & 0,00 & 0,00 & $0,00^{\mathrm{c}}$ \\
R2 & 3,31 & 3,38 & 3,56 & $3,41^{\mathrm{b}}$ \\
R3 & 3,91 & 4,20 & 3,99 & $4,03^{\mathrm{a}}$ \\
\hline
\end{tabular}

Keterangan : angka yang diikuti superscript yang berbeda menunjukkan perbedaan nyata $(P<0,05) ;$ Hasil $0=$ tidak ada zona hambat yang terbentuk.

Hasil analisis sidik ragam menunjukkan bahwa terjadi beda nyata antar perlakuan $(\mathrm{P}<0,05)$. Rerata uji antagonistik ekstrak rosella terhadap bakteri $S$. aureus tertinggi diperlihatkan pada perlakuan ekstrak rosella $60 \%(4,03 \mathrm{~mm})$ dan nilai rerata terendah diperlihatkan pada perlakuan nitrat $\mathrm{R} 1(0,00)$ dan aquades steril (kontrol) R0 (0,00). Hal ini menunjukkan bahwa ekstrak rosella memiliki kemampuan sebagai anibakteri sesuai penelitian Febriyanto et al. (2019), khasiat kelopak rosella adalah sebagai antibakteri. Kemampuan esktrak rosella dalam menghambat bakteri $S$. aureus disebabkan oleh kandungan senyawa flavanoid, tanin, polifenol, saponin, alkaloid dan steroid.

Mekanisme kerja senyawa aktif ekstrak rosella dalam menghambat pertumbuhan bakteri S. aureus yaitu flavonoid dapat menghambat pertumbuhan bakteri $S$. aureus dengan cara mengganggu permeabilitas dinding sel bakteri, dengan terganggunya dinding sel akan menyebabkan lisis pada sel (Dewi, 2010). Beberapa literatur pendukung menyebutkan bahwa senyawa fenol memiliki aktivitas antibakteri dimana flavonoid adalah salah satu kelompok senyawa polifenol (Sukadana, 2010; Juliantini et al., 2006). Polifenol memiliki kemampuan untuk mendenaturasikan protein dan merusak membran sel sehingga mampu menghambat pertumbuhan bakteri S. aureus (Rahayu, 2000). Tanin juga menyerang polipeptida dinding sel sehingga menyebabkan kerusakan dinding sel pada bakteri (Ji, 2012). Menurut Juliantina et al. (2009) senyawa tanin mampu menghambat pertumbuhan bakteri dengan cara mengkoagulasi protoplasma bakteri. Tanin memiliki peran sebagai antibakteri dengan cara mengikat protein sehingga pembentukan dinding sel akan terhambat.

Uji antagonistik ekstrak rosella terhadap bakteri $S$. aureus pada perlakuan nitrat R1 $(0,00)$ dan aquades steril R0 $(0,00)$ tidak menghasilkan zona hambat (zona bening). Hal ini disebabkan karena aquades merupakan senyawa netral yang tidak mengandung racun ataupun zat-zat yang dapat menghambat pertumbuhan bakteri. Sehingga yang dihasilkan dari R0 (kontrol) adalah tumbuh bakteri $S$. aureus pada permukaan media NA. Hal ini menyimpulkan bahwa aquades steril tidak memberi efek antibakteri terhadap bakteri $S$. aureus oleh karena sifat dari aquades. Hasil penambahan nitrat (R1) memiliki nilai rerata yang sama yaitu 0,00 . Hasil ini menunjukkan bahwa nitrat tidak memiliki kemampuan sebagai antibakteri terhadap salah satu bakteri gram positif yaitu $S$. aureus.

Hasil uji lanjut menunjukkan R2 dan R3 ada perbedaan yang disebabkan karena konsentrasi ekstrak rosella pada R3 lebih besar dari konsentrasi ekstrak pada R2. Khasanah (2014) menyatakan bahwa semakin tinggi konsentrasi suatu ekstrak semakin tinggi komponen zat aktif yang terkandung didalamnya. Hasil R3 berbeda nyata dengan hasil R0 dan R1, adanya aktivitas antibakteri dalam ekstrak rosella karena kandungan senyawa gossypetin (Mounnissany et al., 2002; Mahadevan et al., 2009). Senyawa tanin juga berperan dalam aktivitas antibakteri rosella karena dengan cara menunrunkan proliferasi bakteri dengan menghambat aktivitas enzim pada metabolisme bakteri (Mungole dan Chaturvedi, 2011) sehingga senyawa aktif ini menghambat terhadap aktivitas $S$. aureus.

Perlakuan R0 dan R1 tidak berbeda nyata pada uji antogonistik terhadap bakteri $S$. aureus disebabkan karena pada R0 dan R1 sama tidak memiliki kemampuan dalam menghambat atau membunuh bakteri yang ditunjukkan dengan sumur yang berisi aquades tidak memiliki zona bening.

\subsection{Kualitas Mikrobiologis Dendeng Sapi (TPC)}

Dendeng merupakan produk makanan yang terbentuk lempengan terbuat dari daging sapi segar dana tau daging beku, yang diiris tipis atau digiling ditambahkan bumbu dan dikeringkan dengan sinar matahari atau alat pengering lainnya, dengan atau tanpa penambahan bahan pangan lain dan bahan tambahan pangan yang diizinkan (Badan Standarisasi Nasional, 2013). Kadar air dendeng mencapai $12 \%$ masih menjadi media yang baik sebagai media pertumbuhan mikroba, sehingga perlu dilakukan uji secara biologis untuk mengetahui jumlah cemaran bakteri yang ada dalam dendeng. Koloni yang tumbuh menunjukkan jumlah seluruh mikroorganisme yang ada di dalam sampel seperti: bakteri, kapang, dan khamir (Krisna, 2005). Hasil perhitungan TPC dendeng sapi menggunakan colony counter dapat dilihat pada Tabel 2.

\begin{tabular}{ccccc}
\multicolumn{3}{l}{ Tabel 2. Hasil TPC Dendeng Sapi } & \multirow{2}{*}{ Rata-rata } \\
\cline { 2 - 4 } Perlakuan & I (CFU/g) & II (CFU/g) & III (CFU/g) & \\
\cline { 2 - 4 } & TBUD & TBUD & TBUD & TBUD $^{\mathrm{c}}$ \\
R0 & 316,00 & 326,00 & 334,00 & $325,33^{\mathrm{a}}$ \\
R1 & 34,00 & 32,00 & 19,00 & $28,33^{\mathrm{b}}$ \\
R2 & 8,00 & 17,00 & 1,00 & $8,67^{\mathrm{a}}$ \\
\hline Reterangan $:$ angka yang diikuti superscript yang berbeda menunjukkan perbedaan nyata
\end{tabular}

Keterangan : angka yang diikuti superscript yang berbeda menunjukkan perbedaan nyata $(P<0,05) ;$ Hasil $0=$ tidak ada zona hambat yang terbentuk; TBUD = terlalu banyak untuk dihitung

Hasil sidik ragam menunjukkan bahwa perlakuan berpengaruh nyata $(\mathrm{P}<0,01)$ berdasarkan perhitungan TPC. Hasil tertinggi yang ditunjukkan pada Tabel 2 menunjukkan bahwa penambahan nitrat atau sendawa pada dendeng tidak mampu menekan pertumbuhan koloni bakteri. Cemaran pada daging yang menjadi bahan dasar produk dendeng diduga berasal dari RPH sehingga setelah melalui proses pemanasan atau pengeringan masih mengakibatkan pertumbuhan koloni bakteri pada media agar setelah diinkubasi selama 24 jam. Namun, hasil dari penambahan nitrat dalam dendeng berbeda dengan Soeparno (2005), yaitu penambahan nitrat pada curing preservatif mikrobial mempunyai pengaruh bakteriostatik. Menurut Winarno (1997), bahwa garam nitrit dan nitrat yang digunakan dalam proses curing daging untuk memperoleh warna yang baik dan mencegah pertumbuhan mikroba. Hasil uji lanjut menunjukkan bahwa R1 dan R3 tidak berbeda nyata namun perlakuan yang diberi menghasilkan nilai TPC yang tinggi pada perlakuan R1. Hasil ini menggambarkan bahwa R1 dengan penambahan nitrat mempunyai kemampuan yang rendah dalam menghambat pertumbuhan koloni bakteri dalam produk dendeng. Hasil pada penambahan ekstrak rosella $60 \%$ dengan total pertumbuhan mikroba 8,67 CFU/g memiliki kemampuan yang tinggi dalam menghambat pertumbuhan koloni bakteri sehingga TPC yang dihasilkan dari 
perhitungan menggunakan colony counter sedikit. Pada perlakuan R2 dengan ekstrak rosella $40 \%$ menunjukkan hasil TPC yang berbeda nyata dengan R1 dengan hasil 28,33 CFU/g. Hal ini disebabkan karena kadar senyawa aktif antibakteri pada ekstrak rosella lebih rendah dibandingkan dengan konsentrasi $60 \%$. Hasil ini sesuai dengan pernyataan Khasanah (2014), bahwa semakin tinggi konsentrasi suatu ekstrak maka semakin tinggi komponen zat aktif yang terkandung didalamnya dan semakin rendah konsentrasi suatu bahan maka semkain rendah pula senyawa aktif yang ada didalamnya

Populasi total mikroba maksimal pada produk dendeng menurut BSN (2009) adalah $5 \log _{10} \mathrm{CFU} / \mathrm{g}$. batas cemaran mikroba sedikit berbeda dengan BSN jika dibandingkan dengan penelitian ini berdasarkan hasil perhitungan TPC. Hal ini dapat terjadi sesuai dengan pernyataan Pegg dan Sahidi (2006), bahwa pertumbuhan mikroba dan jamur dapat terjadi selama perendaman pada curing basah meskipun daging disimpan dalam suhu dingin dan terdapat kandungan garam dalam larutan curing. Hal tersebut terjadi karena adanya kandungan air yang tinggi selama perendaman daging dalam larutan curing.

Kualitas mikrobiologi daging dapat dipengaruhi oleh sanitasi dan hygiene lingkungan (Farouk et al., 2015). Diantaranya, sarana dan prasarana tempat pemotongan, kondisi ternak sebelum disembelih, proses penyembelihan dan penanganan daging, proses pengangkutan daging sampai ke tangan konsumen. Dilanjutkan oleh Martinez et al. (2015), semua hal yang berkontak langsung dengan daging seperti meja, peralatan dan lingkungan dapat menjadi sumber kontaminasi.

\section{Simpulan}

Ekstrak rosella memiliki kemampuan sebagai antibakteri terhadap bakteri S.aureus dengan terbentuknya zona hambat (zona bening) pada konsentrasi $40 \%$ dan $60 \%$. Ekstrak rosella memiliki kemampuan dalam menghambat pertumbuhan koloni bakteri pada produk dendeng.Pengawet sintetik (nitrat) tidak memiliki kemampuan dalam menghambat ataupun membunuh bakteri.

\section{Pustaka}

Badan Standarisasi Nasional (BSN). SNI 7388:2009. Batas Maksimum Cemaran Mikroba dalam Pangan. BSN. Jakarta.

Badan Standarisasi Nasional (BSN). SNI 01-2908-2013. Dendeng Sapi. BSN Jakarta.

Bintoro, V.P 2008. Teknologi Pengolahan Daging dan Analisis Produk. Universitas Diponegoro, Semarang.

Chotiah, S. 2009. Cemaran Staphylococcus aureus Pada Daging Ayam dan Olahannya. Seminar Nasional Teknologi Peternakan dan Veteriner, 682 687.

Cisse. M., F. Vaillant., O. Acosta., C. Dhuique-Mayer., and M. Dornier. 2009. Thermal Degradation Kinetics of Anthocyanins from Blood Orange, Blackberry, and Roselle Using The Arrhenius, Eyring, and Ball Models J Agricultural and Food Chemistry 57(14):6285-6291.

Dewi, F.K. 2010. Aktivitas antibakteri ekstrak etanol buah mengkudu (Morinda citrofolia L) terhadap bakteri daging segar. [Skripsi]. Universitas Sebelas Maret. Surakarta.

Farouk, M.M., H.M Al-Mazeedi., A.B Sabow., A.E.D Bekhit., K.D Adeyemi., A.Q Sazili and A. Ghani. 2014. Halal and Koshe slaughter methods and meat gualitid: A Review. Meat Science, 98 (3) : 505-519.

Febriyanto, T., R. Meinisasti., J. Farizal dan D.D. R Mawardi. 2019. Uji Daya Hambat Ekstrak Kelopak Bunga Rosella (Hibiscus sabdariffa L.) sebagai antibakteri Staphylococcus aureus. Jurnal Bahana Kesehatan Masyarakat, 3 (1) : 6-8.

Hapsari S. W. N. 2010. Pengaruh Ekstrak Jahe (Zingiber officinale) Terhadap Penghambatan Mikroba Perusak Pada Ikan Nila (Oreochromis niloticus). [Skripsi]. Fakultas Ilmu Kesehatan, Universitas Muhammadiyah Surakarta.

Ji, Y.S., N.D Lestari dan T. Rinanda. 2012. Uji Aktivitas Antibakteri Ekstrak Etanol Kelopak Bunga Rosella (Hibiscus sabdariffa L.) Terhadap Streptococcus pyogenes Secara In Vitro. Jurnal Kedokteran Syiah Kuala, $12(1): 31-36$

Joint FAO/WHO Expert Committee on Food Additives. 2002. The Joint FAO/WHO Expert Committee on Food Additives (JECFA):Evaluation of Certain Food Additives. Geneva $(\mathrm{CH})$ : JECFA.

Juliantina R.F., Citra M.D.A., Nirwani B., NurmasitohT., Bowo E.T. 2009. Manfaat Sirih Merah (Piper crocatum) sebagai agen anti bacterial terhadap bakteri gram positif dan gram negative. Jurnal kedokteran dan kesehatan indonesia.

Komala, O., R. Rosyanti dan Muztabadihardja. 2013. Uji Efektivitas Antibakteri Ekstrak Etanol dan Ekstrak Air Kelopak Bunga Rosella (Hibiscus sabdariffa L) Terhadap Bakteri Streptococcus pneumoniae. Fitofarmaka, Vol 3, No. 1 : 177-183.

Kapitan, O.B., L. Ambasari dan S. Falah. 2017. In Vitro Antibakteri Ekstrak Etanol Puni (Zingiber zerumber) Asal Pulau Timor. Savana cendana, 2 (2) : 29-32.

Khasanah, I., Sarwiyono dan Surjowardojo, P. 2014. Ekstrak etanol daun kersen (Muntingia calabura L.) sebagai antibakteri terhadap Streptococcus agalactiae penyebab mastitis subklinis pada sapi perah [Skripsi]. Fakultas Peternakan, Universitas Brawijaya. Malang. Water Tap $\operatorname{ITB}(1)$. http://www.itb.ac.id/news/557.xhtml. [Diakses 6 Juni 2019].

Martinez-Chaves. L., E. Cabrera-Diaz., J.A Perez-Montano., L.E Garay Martinez., J.J Varela-Hernandez., A. Castillo., L. Lucia., M.G AvilaNovoa., M.A Cardona-Lopez., P. Gutierrez-Gonzalez., N.E MartinezGonzalez. 2015. Quantitative distribution os Salmonella spp and escherechia coli on beef carcass and raw beef at retail establishments. International J. Of Food Microbiology, 210 (1) : 149-155.

Mahadevan, N., Shivali and P. Kamboj. 2009. Hibiscus sabdariffa Linn-an overview. Natural product radiance, 8 (1) : 77-83.

Mpila D.A, Fatimawali., W.I. Wiyono. Uji Aktivitas Antibakteri Ekstrak Etanol Daun Mayana (Coleus atropurpureus [L] Benth) terhadap Staphylococcus aureus, Escherichia colidan Pseudomonas aeruginosa secara In-Vitro. Manado: Fakultas Matematika dan Ilmu Pengetahuan Alam Universitas Sam Ratulangi, 13-21.

Mungole, A dan A, Chaturvedi. 2011. Hibiscus sabdariffa L a rich source of secondary metabolites. International J. Of Pharmaceutical Science Review and Research, 6 (1) : 83-87.

Mounnissany, V.M., S. Kavimani and R. Gunasegaran. 2002. Antibacterial activity of gossypetin isolated from hibiscu sabdariffa. The Antiseptic, 99:81-82.

Nurwantoro., V.P. Bintoro., A.M. Legowo., A. Purnomoadi., L.D. Ambara., A. Prakoso, dan S. Mulyani. 2012. Nilai pH, kadar air, dan total Escherichia Coli daging sapi yang dimarinasi dalam jus bawang putih. Jurnal Aplikasi Teknologi Pangan, 1 (2):20-22.

Pegg, R.B and F. Sahidi. 2006. Processing of nitrit-free cured meats. In: Nollet, L.M.L and F. Toldra. Ed. Advance technologies for meat processing.

Prescott, L.M.; Harley, J.P. and Klein, D.A., 2005, Microbiology, Ed ke-6, McGraw Hill, New York.

Rahayu, P.W. 2000. Aktvitas antimikroba bumbu masakan tradisional hasil olahan indsutri terhadap bakteri patogen dan perusak. Buletin teknologi dan industri pangan, 11 (2) : 42-48.

Rahmi, Y., Darmawi., M. Abrar., F. Jamin., Fakhrurrazi dan Y. Fahrimal. 2015 Identifikasi Bakteri Staphylococcus aureus pada preputium dan vagina kuda (Equus caballus). Jurnal Medika Veterinaria, 9 (2) : 154-158.

Rostinawati, Tina. 2009. Uji Aktivitas Antibakteri Ekstrak Bunga Rosella (Hibiscus sabdariffa L) Terhadap Bakteri E.Colli. Laboratorium Mikrobiologi Putra Indonesia Malang.

Soeparno, 2005. Ilmu dan Teknologi Daging. Cetakan kelima. Gadjah Mada University Press. Yogyakarta.

Sukadana, I.M. 2010. Aktivitas Antibakteri senyawa flavanoid dari kulit akar awar-awar (Ficus septica). J. Kimia, 4 (1) : 63-70.

Suzery, M., S. Lestari dan B. Cahyono.2010. Penentuan total antosianin dari kelopak bunga Rosela (Hibiscus sabdariffa L) dengan metode maserasi dan sokshletasi. Jurnal sains dan Matematika, 18 (1) : 1-6.

Winarno, F.G. 1997. Kimia Pangan dan Gizi. PT. Gramedia Pustaka Utama. Jakarta 